\title{
Kapsayıcı Eğitim Bağlamında Öğretmenlerin Mülteci Öğrencilere İlişkin Tutumlarının Çeşitli Değişkenler Açısından İncelenmesi
}

DOI: $10.26466 /$ opus.612341

\author{
Hilal Kazu* - Emrullah Deniz ** \\ * Doç. Dr, Fırat Üniversitesi, Eğitim Fakültesi, Eğitim Bilimleri Bölümü, Merkez/Elazığ/Türkiye \\ E-Posta: hkazu@firat.edu.tr ORCID: 0000-0001-9380-331X \\ ** Doktora Öğr., Fırat Üniversitesi, Eğitim Bilimleri Enstitüsü, Merkez/Elazı̆̆ / Türkiye \\ E-Posta: emrullah0047@hotmail.com ORCID: 0000-0002-3763-2234
}

Öz

$B u$ araştırmanın amacı, öğretmenlerin mülteci öğrencilere ilişkin tutumlarını cinsiyet, kıdem, sını ya da diğer branş öğretmeni olma durumu, öğrenim durumu, sinıflarında mülteci öğrenci bulunma durumu ve mülteci öğrencilerle ilgili eğitim alma durumuna göre incelemektir. Araştırmada betimsel ve ilişkisel tarama modelleri birlikte kullanılmıştır. 2018-2019 eğitim-öğretim yılında gerçekleştirilen araştırmaya, Güneydoğu Anadolu Bölgesi'nde yer alan bir ilde eğitimin çeşitli kademelerinde görevli toplam 110 (60 kadın, 50 erkek) öğretmen katılmıştır. Araştırma sürecinde ölçme aracı olarak "Mülteci Öğrenci Tutum Ölçeği" kullanılmıştır. Bu çalışmada ölçeğin tamamı için belirlenen Cronbach Alpha katsayısı .89'dur. Verilerin analizinde betimleyici istatistik (frekans, yüzde ve ortalama), Mann Whitney U testi ve Kruskal Wallis H testleri kullanılmıştır. Verilerin karşılaştırılmasında anlamlılık düzeyi .05 olarak kabul edilmiştir. Araştırmanın bulgularn incelendiğinde; öğretmenlerin mülteci öğrencilere yönelik tutumlarının genel olarak "katılıyorum" düzeyinde olduğu; kıdem açısından yeterlik alt boyutunda, sinfflarında mülteci öğrenci bulunma açısından iletişim alt boyutunda ve sinıf ya da diğer branş öğretmeni olma açısından sinıf öğretmenleri lehine anlamlı farklılıkların olduğu görülmüştür.

Anahtar Kelimeler: Mülteci öğrenci, tutum, öğretmen, eğitim, kapsayıcı eğitim 


\title{
An Examination of the Teachers' Attitudes Towards The Refugee Students in Terms of Various Variables Within the Scope of Inclusive Education
}

\begin{abstract}
The purpose of this study is to examine the teachers' attitude regarding the refugee students according to their gender, professional seniority, their situation for being class or other branch teacher, education status, the existence of refugee students in their classes and receiving education related with refugee students. Descriptive and relational survey models were used together in the research. Totally 110 (60 female, 50 male) teachers who are assigned in various stages of the education in a province in Southeastern Anatolia attended into the study which was conducted in 2018-2019 academic year. In the research process, "Refugee Student Attitude Scale" which was developed by Sağlam and Kanbur (2017) was used. In this study, the Cronbach Alpha coefficient which is determined for the entire scale is; .89. For the analysis of the data, descriptive statistic (frequency, percentage and average), Mann Whitney $U$ test and Kruskal Wallis $H$ tests were used. For the comparison of data, significance level was accepted as; .05. When the findings of the study are examined; it is hereby seen that; the attitudes of the teachers towards the refugee students are generally at "I attend" level. However, independent findings of the study hereby revealed that; significant variations occurred in favor of the class teachers in competence sub-dimension according to professional seniority variable, in the communication subdimension according to the variable of existence of refugee students in their classes and according to variable of being a class or other branch teacher.
\end{abstract}

Keywords: Refugee student, attitude, teacher, education, inclusive education 


\section{Giriş}

Savaş, afet veya başka nedenlerle yaşadıkları yerleri terk edip yeni yaşam yerlerine sığınan ve buralarda mülteci olarak barınmaya çalışan bireyler çeşitli zorluklarla karşılaşmaktadırlar. Göç edilen yeni yaşam alanları mülteciler için çeşitli fırsatlar sunduğu gibi, yaşamdaki değişimlere bağlı olarak birçok zorluklar da barındırmaktadır. Göçün yarattığ travma ve sonrasında eşlik eden toplumsal süreçler bireyleri olumsuz etkileyebilmektedir. Göç edenlerin sadece yetişkinlerden oluşmaması, çeşitli yaş gruplarından ve özellikle küu̧ük yaş grubunda yer alan bireylerden oluşması, yaşanan psikolojik süreçlerin ne denli önemli olduğunu ortaya koymaktadır (Ferris ve Winthrop, 2010, s.29; Yavuz ve Mizrak, 2016).

Göç ile birlikte bireylerin yaşamlarında barınma, sağlık ve bakım hizmetlerinin yanında eğitim de kesintiye uğramaktadır. Eğitimin kesintiye uğraması, bireylerin öğrenme ortamlarından, öğretmenlerinden ve arkadaşlarından uzaklaşmasına, eğitim haklarının gecikmesine ya da durmasına neden olabilmektedir. Diğer taraftan, bireylerin yasalarca gözetilen eğitim haklarının korunması (Pigozzi, 1999), doğal ve insan kaynaklı göç sonucunda aksayan eğitim sürecinin normal standartlara uygun ve yaşamın normal akışını destekleyici şekilde sürdürülmesinin devletler tarafından sağlanması gerektiği ifade edilmektedir (Sinclair, 2007, s.52). Eğitim, mülteci öğrencilerin akranlarıyla paralel düzeyde gelişmelerini desteklemenin yanında, uyum becerilerinin gelişimini hızlandıran işlevler de görmektedir (UNESCO, 2006; Ferris ve Winthrop, 2010). Bununla birlikte eğitimin, mülteci öğrencilerin yaşadığı zorluklarla başetme becerilerini geliştirdiği (Mackinnon, 2014), yaşanılan olağandışı durumun olumsuz etkilerini azalttığ1 ve çevreye karşı daha korumacı olmalarını sağladığı (Sinclair, 2007, s.52) belirtilmektedir. Eğitimin mülteci öğrenciler için vazgeçilmez bir unsur olduğunun farkında olan devletler, mülteci öğrencilerin eğitime erişimleri ile ilgili olarak çeşitli yasal düzenlemeler, politikalar ve eğitim uygulamaları yürütmektedirler. Mülteci öğrencilere sunulan eğitim hizmetleri; yaşadıkları sosyal ve kültürel problemler, ortak dil kullanmada yaşanan sorunlar ve uyum problemleri nedeniyle yerleşik öğrencilere göre farklı1ık göstermektedir. Bu farklılıkların azaltılması ve 
ortak kültür temelinde eğitim olanaklarının oluşturması amacıyla çeşitli standartlar oluşturulmaktadır. Bu standartlardan birini temsil eden INEE'ye (Inter-Agency Network for Education in Emergencies) (2010) göre, bu öğrencilere sunulacak eğitimin ilkeleri şu şekilde sıralanmaktadır:

- İnsan haklarına saygılı ve bu hakları koruyucu nitelikte olmal1dir.

- Öğrencilerin yaşanılan olumsuz yaşantı ile başetmesini sağlamalidır.

- Ulaşımı kolay ve ücretsiz olmalıdır.

- Öğrenci ihtiyaçlarının farkında olan ve donanımlı kişilerce yürütülmelidir.

- Koşullara duyarlı, uyarlama yapılabilen ve gerektiğinde geçici eğitim veya uzaktan eğitim olanaklarını içermelidir.

Yukarıda ifade edilen ilkelerin yanı sıra, bu öğrencilerin eğitsel ihtiyaçlarının karşılandığı okul ekosistemine dahil olmaları (Şeker ve Aslan, 2015, s.92) ve okullardaki kurul ve komisyonlara üye olmalarının, öğrencilerin kişilik gelişimlerini olumlu yönde etkilediği (Türmen, 2012, s.13) ifade edilmektedir.

Göçün etkilediği bütün ülkelerde olduğu gibi Türkiye'de de göç sonrasında oluşan mülteci öğrenci popülasyonu dikkate alınarak çeşitli tedbirler alınmaktadır. Ülkemiz, Göç İdaresi Genel Müdürlüğü verilerine göre toplam 3.606.737 Suriye vatandaşını barındırmakta olup; bu nüfusun \%46,1'ini 0-18 yaş aralığında yer alan genç nüfus oluşturmaktadır (URL 1). Ülkemiz ev sahipliğinde barınan mültecilerin büyük çoğunluğu okul çağında yer almakta ve buna yönelik, sosyal ve ekonomik yapıda alınan tedbirlerin yanı sıra eğitim bağlamında da birtakım tedbirler alınmakta ve buna bağlı olarak yeni eğitim uygulamaları yaşama geçirilmektedir. Bu uygulamalardan biri olan kapsayıcı eğitim, "öğrenenlerin farklı gereksinimlerine, onlarn eğitime, kültüre ve topluma katılımını artırarak eğitim sisteminin içindeki ayrımcılı̆̆ azaltarak cevap verme süreci" olarak tanımlanmaktadır (UNESCO, 2005, s. 13). Kapsayı1 eğitim, bütün öğrencilerin ortak bir vizyon temelinde akranlarıla birlikte okul yaşamına aktif olarak katılması, eğitim politikalarının, öğretim programlarının ve öğrenme ortamlarının farklı öğrenme ihtiyaçlarını karşılayacak şekilde uyarlanmasını öngörmektedir (Öztürk 
vd., 2009, s.16). Buna göre öğrenciler arasında var olan farklılıkların ve öğrencilerin farklılaşan ihtiyaçlarının sorun olarak değil, çok kültürlülük temelinde bir firsat olarak ele alınması gerekmektedir (UNESCO, 2005). $\mathrm{Bu}$ yönüyle kapsayıcı eğitimin, mülteci öğrencilerin eğitim sistemine hızlı bir şekilde entegre olmasını hedeflediği söylenebilir. Kapsayıcı eğitimin içerdiği yenilikçi dinamikler ve buna bağlı oluşan felsefi değişim sadece kurumsal düzeyde değil, aynı zamanda öğrenci çeşitliliğini benimseyen ve destekleyen olumlu okul ikliminin oluşmasında da etkili olmaktadır (Öztürk vd., 2009, s. 17). Kapsayıcı eğitim kapsamında ülkemizde Milli Eğitim Bakanlığı tarafından "Kapsayıcı Eğitim Projesi" yürütülmektedir. Öğretmen eğitimine ve niteliğine odaklanan UNICEF destekli projenin ilk safhasında Geçici Eğitim Merkezlerinde görevli "Suriyeli Öğretmenlerin Eğitimi" olarak adlandırılan ve Suriyeli öğretmenlere sunulan destek eğitimleri yer almaktadır. Projenin ikinci safhası "Sınıfında Yabancı Uyruklu Öğrenci Bulunan Öğretmen Eğitimi" adı altında yabancı uyruklu öğrencilerin eğitiminden sorumlu olan öğretmenlerin desteklenmesi amacıyla yapılan eğitimlerden oluşmaktadır. Projenin son safhasında ise, "Kapsayıcı Eğitim", Erciyes Üniversitesi ve UNICEF ortaklığında 10 modül olarak yeniden geliştirilerek uygulanmaktadır. İlgili projede, öğretmenlerin, öğrenci çeşitliliğini benimsemesi, ayrım gözetmeden öğrencilere yaklaşması, öğrenci ihtiyaçlarının farkında olması ve bu doğrultuda öğrenme alanlarında uyarlamalar yapabilmesi hedeflenmektedir. Devam etmekte olan bu proje kapsamında eğitici eğitimi alan 1672 öğretmen, ülke genelinde yerel hizmet içi eğitim programları düzenleyerek, tüm öğretmenlerin "Kapsayıcı Eğitim" projesinin içerdiği eğitimlerle desteklenmesini sağlamaktadırlar (MEB, 2018).

Alanyazında mülteci öğrencilerin eğitimini temel alan çalışmalara bakıldığında; mülteci öğrencilerin eğitimi ile ilgili merkezlerin yönetiminde (Balkar vd., 2016), eğitim-öğretim ortamlarında (Börü ve Boyac1, 2016), öğrencilerin akademik becerilerinde (Baltacı, 2014; Güngör ve Şenel, 2018; Gömleksiz ve Aslan, 2018), öğrencilerin dili etkin kullanabilmelerinde (Başar vd., 2018; Kuzu vd., 2018), öğretim programı ve içerik uyarlanmasında (Zayimoğlu Öztürk, 2018), öğretmenlerin yaklaşımlarında (Er ve Bayındır, 2015), öğrencilerin uyum sağlama becerilerinin geliştirilmesinde (Mercan vd., 2016; Kiremit vd., 2018) ve kamu 
politikaları oluşturma süreçlerinde (Özer vd., 2016) çeşitli zorluklar yaşandı̆̆ 1 görülmektedir. Diğer taraftan, mülteci öğrencilerin eğitimöğretim sürecine dahil edilmelerinin uyumu kolaylaştırdığı (Croce, 2018), öğrenciler için güven ortamı sağladığı (Boutun, 2016; Alharbi, 2017), marjinalleşmeyi önleyip akran etkileşimini artırdığ1 (McParker, 2018) ve bunlara bağı olarak da kültürleşme, sosyal adaptasyon ve akademik başarıda olumlu gelişmelerin yaşandığına (Miller vd., 2005) işaret eden çalışmalara da rastlanmaktadır. Mülteci öğrencilerle ilgili yapılan çalışmalar, mülteci öğrencilerin eğitime devam etmelerinin ötesinde, istenen sonuçlara ulaştıracak daha etkili müdahalelere ihtiyaç duyulduğunu göstermektedir. Bu nedenle bu öğrencilerle ilgili eğitsel kararlar alınırken, etkililiği bilimsel çalışmalarla kanıtlanmış yöntemlerin benimsenmesi ve uygulanması, davranış değişikliği yaratmada etkili olmaktadır.

Mülteci öğrencilere yönelik hedeflenen öğrenme çıtılarının gerçekleşmesi için; öğrenci özelliklerine (çok kültürlülük) odaklı öğrenme ortamlarının oluşturulması, uyarlanmış içeriklerin sunulması, uygun öğretim yöntem ve tekniklerin seçilmesi ve hedeflere odaklı ölçme araçlarının kullanılması gerektiği (Taylor ve Sidhu, 2012) ifade edilmektedir. Bu bileşenlerin sürekli bir döngüye dönüşebilmesi ise destekleyici öğrenme ortamlarının oluşturulması ile mümkündür. Dolayısıyla, mülteci öğrencilerin eğitim ortamlarına başarılı bir şekilde entegre edilmelerinin formal eğitim uygulamalarının yanında, kültürel farklılıklara duyarlı, öğrenci eğitim durumlarının önemsendiği, yönetici ve öğretmenlerin işbirliği içinde oldukları ve öğretmen yeterliklerinin geliştirildiği bir ekosisteme bağlı olduğu söylenebilir.

MEB öncülüğünde yürütülen kapsayıcı eğitim, alanyazında öne çıarılan bütün bileşenleri içermese de; öğretmen ve yönetici tutumlarında değişimi, çok kültürlülüğü içeren olumlu bir okul iklimi oluşturmayı ve mülteci öğrencilerle ilgili bir kavrayışın gelişmesini hedeflediği söylenebilir. Belirlenen bu hedeflerin gerçekleşebilmesi ise, programın yürütücüsü konumunda bulunan öğretmen tutumları ile yakından ilişkilidir. İlgili alanyazında mülteci öğrencilerle ilgili çok sayıda araştırma olmasına rağmen, bu öğrencilerin eğitiminde öğretmen tutumlarının ne düzeyde olduğu ve nasıl etkilendiği ile ilgili araştırma sayısının az sayıda olduğu tespit edilmiştir. Bu durumdan hareketle bu 
araştırmanın genel amacı, çeşitli kademelerde görevli öğretmenlerin mülteci öğrencilere ilişkin tutumlarının incelenmesidir. Bu çalışmada elde edilen sonuçların, ilgili alanyazına bu yönüyle katkı sağlayacağı düşünülmektedir. Bununla birlikte, öğretmen tutumlarının sahip oldukları özellikler ya da birtakım değişkenler/ durumlardan bağımsız olamayacağı öngörülerek aşağıdaki sorulara cevap aranmıştır:

Öğretmenlerin mülteci öğrencilere yönelik tutumları;

1. Cinsiyet değişkeni açısından anlamlı bir farklılık göstermekte midir?

2. Kıdem durumu açısından anlamlı bir farklılık göstermekte midir?

3. Sınıf öğretmeni ya da diğer branş öğretmeni olma durumlarına göre anlamlı bir farklılık göstermekte midir?

4. Öğrenim durumlarına bağlı olarak anlamlı bir farklılık göstermekte midir?

5. Sınıflarında mülteci öğrenci olup olmama durumlarına göre anlamlı bir farklılık göstermekte midir?

6. Mülteci öğrencilerle ilgili eğitim (hizmet içi eğitim, seminer, kurs vb.) alma açısından anlamlı bir farklılık göstermekte midir?

\section{Yöntem}

\section{Araştırmanın Modeli}

Öğretmenlerin mülteci öğrencilere ilişkin tutumlarını belirleyerek, bu tutumların çeşitli değişkenler açısından incelenmesini amaçlayan bu araştırmada, tarama modellerinden betimsel ve karşılaştırma türü ilişkisel tarama (survey) modelleri birlikte kullanılmıştır. Betimsel araştırma modelinde olay ya da olgular olabildiğince tanımlanmaya çalış1lırken (Büyüköztürk vd., 2013, s.24); ilişkisel tarama modellerinde ise, belirlenen değişken durumlarına göre gruplar arasındaki farklılaşma incelenir (Karasar, 2005, s.81). 


\section{Çalışma Grubu}

$\mathrm{Bu}$ araştırmanın çalışma grubu, 2018-2019 eğitim-öğretim yılında Güneydoğu Anadolu Bölgesi'nde yer alan bir ilde eğitimin çeşitli kademelerinde görev yapan 110 öğretmenden oluşmaktadır. Araştırmanın yapılacağı okullar amaçlı örnekleme yöntemlerinden ölçüt örnekleme temel alınarak belirlenmiştir. Amaçlı örnekleme, kapsamlı bilgi içerdiği düşünülen durumların derinlemesine incelenmesine fırsat tanımaktadır (Patton, 2002). Ölçüt örnekleme yöntemi ise, belirlenen bir dizi ölçütleri karşılayan olay ve olguların incelenmesini içermektedir. Bu ölçütler daha önce hazırlanmış olabileceği gibi, araştırmacılar tarafından da oluşturulabilir (Yıldırım ve Şimşek, 2013). Bu araştırmadaki çalışma grubu; mülteci öğrenci popülasyonu yoğun olma ve kapsayıcı eğitim uygulamasını yürütme ölçütleri doğrultusunda belirlenmiştir. Bu amaçla 3 ilkokul, 3 ortaokul ve 2 lisede görevli öğretmenlere ölçeğin dağıtımı gerçekleştirilmiştir. Toplamda 121 öğretmen tarafından yanıtlanan ölçeklerden, ölçeğin tamamına yanıt veren 110 'u değerlendirilmeye alınmıştır. Katılımcılara ait bilgiler Tablo 1'de sunulmuştur.

Tablo 1. Çalışma Grubunun Özellikleri

\begin{tabular}{llll}
\hline Değişken & & $\mathbf{n}$ & $\mathbf{\%}$ \\
\hline \multirow{2}{*}{ Cinsiyet } & Kadın & 60 & 54,5 \\
& Erkek & 50 & 45,5 \\
\hline \multirow{2}{*}{ Görev yapılan öğretim basamağı } & Ilkokul & 29 & 26,3 \\
& Ortaokul & 56 & 51,0 \\
& Lise & 25 & 22,7 \\
\hline \multirow{2}{*}{ Kıdem } & $1-5$ & 42 & 38,18 \\
& $6-10$ & 37 & 33,64 \\
& $11-15$ & 14 & 12,73 \\
Öğrenim düzeyi & 15 ve yukarısı & 17 & 15,45 \\
\hline \multirow{2}{*}{ Sınıflarında mülteci öğrenci bulunma durumu } & Lisans & 101 & 91,9 \\
\hline Mülteci öğrencilerle ilgili eğitim & Lisansüstü & 9 & 8,1 \\
(hizmet içi eğitim, seminer, kurs vb.) alma durumu & Evet & 101 & 91,9 \\
\hline
\end{tabular}

Tablo 1 incelendiğinde öğretmenlerin 60'ının (\%54,5) kadın, 50'sinin $(\% 45,5)$ erkek olduğu görülmektedir. Araştırmaya katılan öğretmenlerin 
$\% 26,3$ 'ü ilkokul, \%51,0'i ortaokul ve \% 22,7'si ise lise öğretim basamağında görev yaptıkları görülmektedir. Öğretmenlerin 42'sinin (\%38,18) 1-5 yıl arası, 37'sinin (\%33,64) 6-10 yıl aras1, 14'ünün (\%12,73) $11-15$ yıl arası ve 17 'sinin $(\% 15,45) 15$ ve yukarısı kıdeme sahip olduğu; 101 'nin $(\% 91,9)$ lisans, 9'unun $(\% 8,1)$ lisansüstü öğrenim düzeyinde olduğu görülmektedir. Sınıfında mülteci öğrenci bulunan öğretmenlerin toplam katılımcların \%91,8'ini (101) oluşturduğu, \%8,2'sinin ise sınıfında mülteci öğrenci bulunmadığı tespit edilmiştir. Ayrıca, öğretmenlerin \%53,6'sının (59) mülteci öğrencilerle ilgili eğitim aldığı (hizmet içi eğitim, seminer, kurs vb.), \%46,4'ünün ise mülteci öğrencilerle ilgili herhangi bir eğitim almadığı belirlenmiştir.

\section{Veri Toplama Araci}

Araştırmada öğretmenlerin mülteci öğrencilere yönelik tutumlarını belirlemek için Sağlam ve Kanbur (2017) tarafından geliştirilen Mülteci Öğrenci Tutum Ölçeği (MÖTÖ) kullanılmıştır. 4'lü likert tipi derecelendirmeye sahip ölçek, üç boyut (iletişim, uyum, yeterlik) ve toplam 24 maddeden oluşmaktadır. Orijinal ölçek alt boyutlarına ilişkin faktör yük değer aralıklarının birinci alt boyut için .45-.75, ikinci alt boyut için .40-.79 ve üçüncü alt boyut için .60-.83 arasında değiştiği ve toplam varyansın \%53,61'ni temsil ettiği belirtilmektedir. Ölçekten alınabilecek en yüksek puan 96 ve en alt puan 24 olup; ölçekten alınan yüksek puanlar, öğretmenlerin mülteci öğrencilere yönelik tutumunun olumlu yönde olduğunu göstermektedir. Ölçeğin yapı geçerliği için doğrulayıcı faktör analizi (DFA) uygulanmış ve uyum indeksi değerlerine bakılmıştır. Sonuçlar, Kline (2005) tarafından önerilen asgari uyum indeksleri (Tablo 2) takip edilerek değerlendirilmiştir. DFA sonucu elde edilen uyum indeksleri Tablo 3'te sunulmuştur.

Tablo 2. DFA Uyum İndekslerine Ait Aralıklar

\begin{tabular}{lll}
\hline Uyum İndeksleri & Kabul Edilebilir Uyum & İyi Uyum \\
\hline$\chi 2 / s d$ & $3 \leq \chi 2 / s d \leq 5$ & $0<\chi 2 / s d \leq 3$ \\
RMSEA & $0,05 \leq \mathrm{RMSEA} \leq 0,10$ & $0 \leq \mathrm{RMSEA} \leq 0,05$ \\
CFI & $0,90 \leq \mathrm{CFI} \leq 0,95$ & $0,95 \leq \mathrm{CFI} \leq 1$ \\
GFI & $0,85 \leq \mathrm{GFI} \leq 0.90$ & $0,90 \leq \mathrm{GFI} \leq 1$ \\
SRMR & $0,05 \leq \mathrm{SRMR} \leq 0,10$ & $0 \leq \mathrm{SRMR} \leq 0,05$ \\
\hline
\end{tabular}


Tablo 2'de sunulan uyum indekslerine ilişkin kesim değerleri dikkate alınarak Tablo 3'teki DFA uyum indekslerini yansıtan değerler yorumlanmıştır.

Tablo 3'te yer alan model uyum değerleri incelendiğinde, ölçeğin verilerle uyumlu olduğu; dolayısıyla, doğrulandığı söylenebilir.

Tablo 3. Mülteci Öğrenci Tutum Ölçeğine İlişkin Uyum İndeksleri

\begin{tabular}{lclccccc}
\hline $\mathbf{n}$ & $\boldsymbol{X}^{\mathbf{2}}$ & $s \boldsymbol{d}$ & $\boldsymbol{\chi 2} / \mathrm{s} \boldsymbol{d}$ & $\mathbf{C F I}$ & GFI & SRMR & RMSEA \\
\hline 110 & 533,4 & 243 & 2,1 & .901 & .880 & .082 & .069 \\
\hline
\end{tabular}

Ölçeğin güvenirliğine ilişkin elde edilen puanların güvenirliği Cronbach Alpha güvenirlik katsayısı ile belirlenmiş ve ölçek toplamı için .91 , iletişim alt boyutu için .88 , uyum alt boyutu için .88 ve yeterlik alt boyutu için .80 olarak hesaplanmıştır. Bu araştırmada ölçeğin uygulanmasıyla elde edilen Cronbach Alpha katsayıları iletişim boyutu için .83 , uyum boyutu için .81 , yeterlik boyutu için .77 ve ölçeğin geneli için .89 olarak hesaplanmıştır.

\section{Verilerin Analizi}

Verilerin analizi yapılmadan önce kayıp veriler ve uç değerler incelenmiş; çarpıklık-basıklık değerlerini içeren veriler ise kontrol edilerek Tablo 4'te sunulmuştur. Kayıp değerlerin frekansı (kayıp veri = 7) ve dağılımına (random) bakıldıktan sonra; Tabachnick ve Fidell (2015) tarafından önerilen, kayıp verilerin yerine serilerin ortalamasını yansıtan değerler atanmıştır.

Öğretmenlerin mülteci öğrencilere yönelik tutumlarını belirlemek amacıyla ölçek ve ölçeğin alt boyutlarına ilişkin aritmetik ortalama puanları yorumlanırken; 1.00-1.74 puan aralığ hiç katılmıyorum, 1.75-2.49 puan aralığ biraz katılıyorum, 2.50-3.24 puan aralığ1 katılıyorum ve 3.254.00 puan aralığ tamamen katılıyorum şeklinde belirlenmiştir.

Araştırmanın bağımsız değişkenlerine göre kullanılacak istatistiksel analizlerin belirlenmesi için, öncelikle ölçekten alınan puanların normal dağılıp dağılmadığına bakılmıştır. Bu amaçla Tabachnick ve Fidell'in (2015) belirttiği gibi, çarpıklık ve basıklık değerinin $p=.05$ anlamlılık düzeyinde $+1,96$ ve $-1,96$ aralığında olmasına dikkat edilmiş; P-P ve Q-Q 
grafikleri incelenerek kontrol edilmiştir. Bu araştırmaya katılan grubun büyüklüğü $(n=110) 50$ 'den büyük olduğu için, verilerin incelenmesinde Kolmogorov-Smirnov testi kullanılmıştır. Dağılım varyansları tüm bağımsız değişkenlerde normal dağılmadığından (K-S(iletişim): .138; p<.05; K-S(uyum): .089; p<.05; K-S(yeterlik): .1,27; $\mathrm{p}<.05$ ) verilerin analizinde normallik varsayımı gerektirmeyen testler kullanılmıştır. $\mathrm{Bu}$ amaçla; öğretmenlerin mülteci öğrencilere yönelik tutumlarını cinsiyet, sınıf ya da diğer branş öğretmeni olma durumu, öğrenim durumu, sınıflarında mülteci öğrenci olma durumu ve mülteci öğrencilere yönelik eğitim alma durumu değişkenleri açısından incelemek için Mann Whitney $\mathrm{U}$ testi; kıdem durumlarına göre incelemek için Kruskall Wallis $\mathrm{H}$ testi kullanılmıştır. Bulunan farkların pratik anlamlarının olup olmadığ1 "etki büyüklüğü istatistiği" kullanılarak hesaplanmıştır. Etki büyüklükleri hesaplanırken; Mann Whitney $U$ testi için $r=\frac{z}{\sqrt{n}}$ formülü, Kruskall Wallis $\mathrm{H}$ testi için ise, epsilon-squared formülü $\left(E_{R}^{2}=\right.$ $\frac{H}{\left(n^{2}-1\right) /(n+1)}$ ) kullanılmıştır (Akt.,Tomcczak ve Tomcczak, 2014). Anılan formüllerde etki büyüklüklerinin 0 ile 1 aralığında bir değer aldığı ve değer 1'e yaklaştıkça mükemmel düzeyde etki büyüklüklerinin elde edildiği ifade edilmektedir (Akt., Tomcczak ve Tomcczak, 2014). Yapılan analiz sonuçları $\mathrm{p}<.05$ anlamlılık düzeyinde değerlendirilmiştir.

\section{Bulgular}

Araştırmanın bu bölümünde Mülteci Öğrenci Tutum Ölçeği ile ilgili betimsel verilerin yanı sıra, öğretmenlerin mülteci öğrencilere yönelik tutumları; araştırmada kullanılan tutum ölçeğinin alt boyutları dikkate alınarak, cinsiyet, kıdem, sınıf ya da diğer branş öğretmeni olma duru$\mathrm{mu}$, öğrenim durumu, sinıflarda mülteci öğrenci bulunma durumu ve mülteci öğrencilerle ilgili eğitim alma durumlarını içeren değişkenlere ilişkin analiz sonuçlarına yer verilmiştir.

Ölçeğin uygulanmasıyla elde edilen betimsel veriler Tablo 4 'te sunulmuştur. 
Tablo 4. Mülteci Öğrenci Tutum Ölçeği'ne İlişkin Betimsel Veriler

\begin{tabular}{llllllll}
\hline Boyutlar & $\mathbf{n}$ & $\mathbf{X}$ & ss & Max & Min & Çarpıklık & Basıklık \\
\hline İletişim & 110 & 3,53 & .379 & 4,00 & 2,36 &,- 779 & .098 \\
Uyum & 110 & 2,82 & .488 & 4,00 & 1,44 &, 134 & .509 \\
Yeterlik & 110 & 2,85 & .706 & 4,00 & 1,50 &, 074 & $-1,020$ \\
Ölçeğin Geneli & 110 & 3,15 & .405 & 4,00 & 2,14 &,- 013 & -.275 \\
\hline
\end{tabular}

Tablo 4 incelendiğinde, öğretmenlerin Mülteci Öğrenci Tutum Ölçeği'nin alt boyutlarından aldıkları puan ortalamalarının sırasıyla, iletişim alt boyutunda $X=3,53$, uyum alt boyutunda $X=2,82$, yeterlik alt boyutunda $X=2,85$ ve ölçeğin genelinde ise $X=3,15$ olduğu görülmektedir. $\mathrm{Bu}$ sonuçlar, mülteci öğrencilere yönelik öğretmen tutumlarının uyum, yeterlik ve ölçek toplaminda "katıliyorum", iletişim alt boyutunda ise "tamamen katılıyorum" seviyesinde olduğunu göstermektedir. Ayrıca, çarpıklık ve basıklık değerlerinin $+1,96$ ve $-1,96$ aralığında olduğu tablo verilerinden anlaşılmaktadır.

Cinsiyete göre öğretmenlerin mülteci öğrencilere yönelik tutumlarının farklılaşıp farklılaşmadığını incelemek amacıyla yapılan Mann Whitney U testi sonuçları Tablo 5'te sunulmuştur.

Tablo 5. Öğretmenlerin Cinsiyet Değişkeni Açısından Mülteci Öğrencilere Yönelik Tutumlarının Karşılaştırılmasına İlişkin Mann Whitney U Testi Sonuçları

\begin{tabular}{|c|c|c|c|c|c|c|}
\hline \multirow[b]{2}{*}{ Boyutlar } & \multirow[b]{2}{*}{ Cinsiyet } & \multirow[b]{2}{*}{$\mathbf{n}$} & \multirow[b]{2}{*}{ Sira Ortalaması } & \multirow{2}{*}{$\begin{array}{l}\text { Siraların } \\
\text { Toplamı }\end{array}$} & \multicolumn{2}{|c|}{$\begin{array}{c}\text { Mann-Whitney U } \\
\text { Testi }\end{array}$} \\
\hline & & & & & $\mathrm{U}$ & $\mathbf{P}$ \\
\hline \multirow[t]{2}{*}{ İletişim } & Kadın & 60 & 57,68 & 3461,00 & \multirow{2}{*}{1369,00} & \multirow{2}{*}{.430} \\
\hline & Erkek & 50 & 52,88 & 2644,00 & & \\
\hline \multirow[t]{2}{*}{ Uyum } & Kadın & 60 & 56,16 & 3369,50 & \multirow{2}{*}{1460,50} & \multirow{2}{*}{.812} \\
\hline & Erkek & 50 & 54,71 & 2735,50 & & \\
\hline \multirow[t]{2}{*}{ Yeterlik } & Kadın & 60 & 50,93 & 3055,50 & \multirow{2}{*}{1225,50} & \multirow{2}{*}{.098} \\
\hline & Erkek & 50 & 60,99 & 3049,50 & & \\
\hline \multirow[t]{2}{*}{ Ölçeğin Geneli } & Kadın & 60 & 55,01 & 3300,50 & \multirow{2}{*}{1470,50} & \multirow{2}{*}{.859} \\
\hline & Erkek & 50 & 56,09 & 2804,50 & & \\
\hline
\end{tabular}

Tablo 5 incelendiğinde, cinsiyete göre öğretmenlerin mülteci öğrencilere yönelik tutumlarının ölçeğin toplamında ( $U=1470,50 ; p>.05)$, iletişim alt boyutunda $(\mathrm{U}=1369,00 ; \mathrm{p}>.05)$, uyum alt boyutunda $(\mathrm{U}=$ $1460,50 ; \mathrm{p}>.05)$ ve yeterlik alt boyutunda $(\mathrm{U}=1225,50 ; \mathrm{p}>.05)$ anlamlı bir düzeyde farklılaşmadığı görülmektedir. 
Öğretmenlerin mülteci öğrencilere yönelik tutumlarının kıdem durumlarına göre farklılaşıp farklılaşmadığını incelemek için yapılan Kruskal Wallis H testi sonuçları Tablo 6'da sunulmuştur.

Tablo 6. Öğretmenlerin Kıdem Açısından Mülteci Öğrencilere Yönelik Tutumlarının Karşılaştırılmasına İliş̧kin Kruskal Wallis H Testi Sonuçları

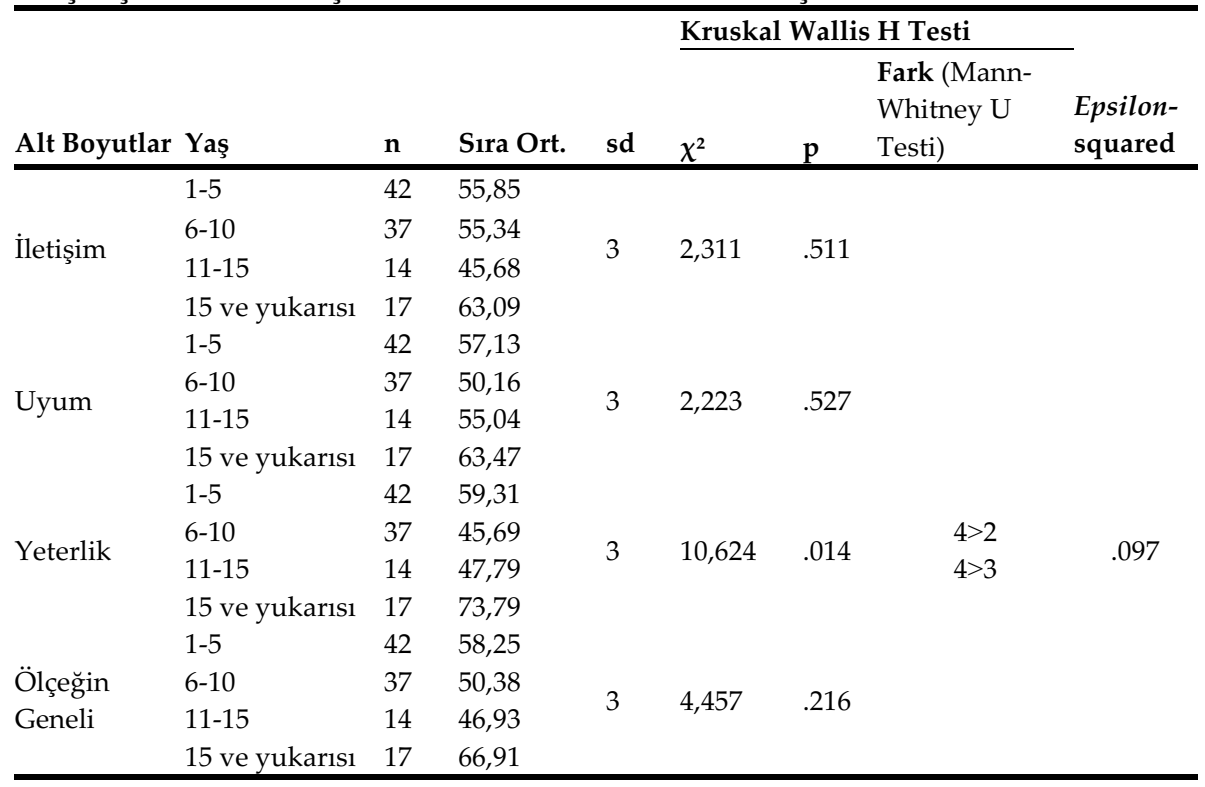

Tablo 6 incelendiğinde, öğretmenlerin kıdem değişkenine göre mülteci öğrencilere yönelik tutumlarının iletişim alt boyutunda $\left(\chi^{2}=2,311\right.$; $\mathrm{p}>.05)$, uyum alt boyutunda $\left(\chi^{2}=2,223 ; \mathrm{p}>.05\right)$ ve ölçeğin genelinde $\left(\chi^{2}=\right.$ 4,457; p>.05) anlamlı bir düzeyde farklılaşmadığı görülmektedir. Bununla birlikte, yeterlik alt boyutunda $\left(\chi^{2}=10,624 ; \mathrm{p}<.05\right)$ anlamlı bir farklılık olduğu görülmektedir. Kruskal Wallis $\mathrm{H}$ testi sonuçlarında görülen farklılığın hangi gruplar arasında olduğunu belirlemek amaciyla gruplar arasında Mann Whitney U testi kullanılmıştır. Analiz sonuçlarına göre yeterlik alt boyutunda 15 ve yukarısı ile 6-10 mesleki kıdem arasında $(\mathrm{p}=$ .005), 15 ve yukarısı ile 11-15 mesleki kıdem arasında $(p=.032)$ istatiksel olarak anlamlı bir farklılık tespit edilmiştir. Analiz sonucunda 15 ve yukarısı mesleki kıdeme sahip öğretmenlerin 6-10 ve 11-15 mesleki kıdeme sahip öğretmenlere göre mülteci öğrenci tutum ölçeği puan sıra ortala- 
malarının daha fazla olduğu tespit edilmiştir. Hesaplanan etki büyüklüğü değerine göre, kıdem değişkeninin yeterlik boyutu üzerindeki etki büyüklüğü (Epsilon-squared = .097) “küçük düzey”dedir.

Araştırmaya katılan öğretmenlerin mülteci öğrencilere yönelik tutumlarının sınıf ya da diğer branş öğretmeni olma durumları açısından anlamlı bir farklılaşmanın olup olmadığını incelemek için yapılan Mann Whitney U testine ilişkin sonuçlar Tablo 7'de sunulmuştur.

Tablo 7. Öğretmenlerin Mülteci Öğrencilere İlişkin Tutumlarının Sınıf Ya Da Diğer Branş Öğretmeni Olma Durumları Açısından Karşılaştırılmasına İlişkin Yapılan Mann Whitney U Testi Sonuçları

\begin{tabular}{|c|c|c|c|c|c|c|c|}
\hline \multirow[b]{2}{*}{ Boyutlar } & \multirow[b]{2}{*}{ Branş } & \multirow[b]{2}{*}{$\mathbf{n}$} & \multirow{2}{*}{$\begin{array}{l}\text { Sira } \\
\text { Ort. }\end{array}$} & \multirow{2}{*}{$\begin{array}{l}\text { Siraların } \\
\text { Toplamı } \\
\end{array}$} & \multicolumn{2}{|c|}{$\begin{array}{c}\text { Mann-Whitney U } \\
\text { Testi }\end{array}$} & \multirow{2}{*}{ Effect size } \\
\hline & & & & & $\mathrm{U}$ & $\mathbf{P}$ & \\
\hline \multirow{2}{*}{ İletişim } & Sınıf Öğretmeni & 29 & 71,29 & 2067,50 & \multirow{2}{*}{716,50} & \multirow{2}{*}{.002} & \multirow{2}{*}{.29} \\
\hline & Diğer Branş Öğretmeni & 81 & 49,85 & 4037,50 & & & \\
\hline \multirow{2}{*}{ Uyum } & Sınıf Öğretmeni & 29 & 64,59 & 1873,00 & \multirow{2}{*}{911,00} & \multirow{2}{*}{.073} & \\
\hline & Diğer Branş Öğretmeni & 81 & 52,25 & 4232,00 & & & \\
\hline \multirow{2}{*}{ Yeterlik } & Sınıf Öğretmeni & 29 & 58,43 & 1694,50 & \multirow{2}{*}{1089,50} & \multirow{2}{*}{.562} & \\
\hline & Diğer Branş Öğretmeni & 81 & 54,45 & 4410,50 & & & \\
\hline Ölçeğin & Sınıf Öğretmeni & 29 & 66,71 & 1934,50 & \multirow{2}{*}{849,50} & \multirow{2}{*}{.027} & \multirow{2}{*}{.21} \\
\hline Geneli & Diğer Branş Öğretmeni & 81 & 51,49 & 4170,50 & & & \\
\hline
\end{tabular}

Tablo 7 incelendiğinde, uygulanan Mann Whitney $\mathrm{U}$ testi sonucunda araştırmaya katılan öğretmenlerin ölçeğin geneli $(U=849,50 ; p<.05)$ ve iletişim alt boyutunda $(\mathrm{U}=716,50 ; \mathrm{p}<.05)$ aldıkları puan sıra ortalamaları bakımından sınıf ve diğer branş öğretmeni olan katılımcılar arasında anlamlı bir farklılık tespit edilmiştir. Bu farklılığın etki büyüklükleri incelendiğinde; sınıf ya da diğer branş öğretmeni olma durumlarının iletişim boyutu (.29) ve ölçeğin geneli (.21) üzerindeki etki büyüklükleri "küçük" miktardadır. Analiz sonuçlarına göre, sınıf öğretmenlerinin diğer branş öğretmenlerine göre ölçeğin geneli ve iletişim alt boyutunda Mülteci Öğrenci Tutum Ölçeği puan sıra ortalamalarının daha fazla olduğu tespit edilmiştir.

Öğretmenlerin mülteci öğrencilere yönelik tutumlarının öğrenim durumlarına bağlı olarak farklılaşıp farklılaşmadığının incelenmesi amacıyla yapılan Mann Whitney $U$ testine ilişkin sonuçlar tablo 8'de gösterilmiştir. 
Tablo 8. Öğretmenlerin Mülteci Öğrencilere Yönelik Tutumlarnın Öğrenim Düzeyi Bakımından Karşılaştırılmasına İlişkin Mann Whitney U Testi Sonuçları

\begin{tabular}{|c|c|c|c|c|c|c|}
\hline \multirow[b]{2}{*}{ Boyutlar } & \multirow{2}{*}{$\begin{array}{l}\text { Öğrenim } \\
\text { Düzeyi }\end{array}$} & \multirow[b]{2}{*}{$\mathbf{n}$} & \multirow[b]{2}{*}{ Sira Ortalaması } & \multirow{2}{*}{$\begin{array}{l}\text { Siraların } \\
\text { Toplamı }\end{array}$} & \multicolumn{2}{|c|}{$\begin{array}{c}\text { Mann-Whitney U } \\
\text { Testi }\end{array}$} \\
\hline & & & & & $\mathbf{U}$ & $\mathbf{P}$ \\
\hline \multirow{2}{*}{ İletişim } & Lisans & 101 & 56,28 & 5684,50 & \multirow{2}{*}{375,50} & \multirow{2}{*}{.387} \\
\hline & Lisansüstü & 9 & 46,72 & 420,50 & & \\
\hline \multirow{2}{*}{ Uyum } & Lisans & 101 & 56,70 & 5727,00 & \multirow{2}{*}{333,00} & \multirow{2}{*}{.184} \\
\hline & Lisansüstü & 9 & 42,00 & 378,00 & & \\
\hline \multirow{2}{*}{ Yeterlik } & Lisans & 101 & 55,50 & 5606,00 & \multirow{2}{*}{454,00} & \multirow{2}{*}{.996} \\
\hline & Lisansüstü & 9 & 55,44 & 499,00 & & \\
\hline \multirow{2}{*}{ Ölçeğin Geneli } & Lisans & 101 & 56,32 & 5688,50 & \multirow{2}{*}{371,50} & \multirow{2}{*}{.365} \\
\hline & Lisansüstü & 9 & 46,28 & 416,50 & & \\
\hline
\end{tabular}

Tablo 8'deki verilere bakıldığında, öğretmenlerin mülteci öğrencilere yönelik tutumlarında; iletişim $(U=375,50 ; p>.05)$, uyum $(U=333,00$; $\mathrm{p}>.05)$, yeterlik $(U=454,00 ; p>.05)$ alt boyutu ve ölçeğin genelinde $(U=$ $371,50 ; p>.05)$ aldıkları puan sira ortalamalarına göre, lisans ya da lisansüstü öğrenim düzeyine sahip öğretmenler arasında anlamlı bir farklılık olmadığı görülmektedir.

Araştırmada bir diğer değişken olarak, öğretmenlerin sınıflarında mülteci öğrenci bulunup bulunmamasına göre tutumlarında farklılaşma olup olmadığı incelenmiştir. Mann Whitney U testi sonuçlarını içeren veriler Tablo 9'da gösterilmiştir.

Tablo 9 incelendiğinde, sınıflarında mülteci öğrenci bulunup bulunmama değişkeni açısından öğretmenlerin mülteci öğrencilere ilişkin tutumlarının iletişim $(\mathrm{U}=255,00 ; \mathrm{p}<.05)$ alt boyutunda anlamlı bir şekilde farklılaştığ 1 ; uyum $(U=416,50 ; p>.05)$, yeterlik $(U=430,50 ; p>.05)$ ve ölçeğin genelinde $(U=388,00 ; \mathrm{p}>.05)$ ise anlamlı bir şekilde farklılaşmadığ1 görülmektedir. Hesaplanan etki büyüklüğü istatistiğine göre, öğretmenlerin sinıflarında mülteci öğrenci olma durumlarının iletişim alt boyutu üzerindeki etkisi (.21) "küçük" miktardadır.

Analiz sonuçlarına göre, sınıflarında mülteci öğrenci bulunan öğretmenlerin, sınıflarında mülteci öğrenci bulunmayan öğretmenlere kıyasla, iletişim boyutunda bu öğrencilere yönelik tutumlarının olumlu yönde etkilendiği söylenebilir. 
Tablo 9. Sınıflarında Mülteci Öğrenci Bulunma Değişkeni Açısından Öğretmenlerin Mülteci Öğrencilere İlişkin Tutumlarının Karşılaştırılmasına İlişkin Yapılan Mann Whitney U Testi Sonuçlan

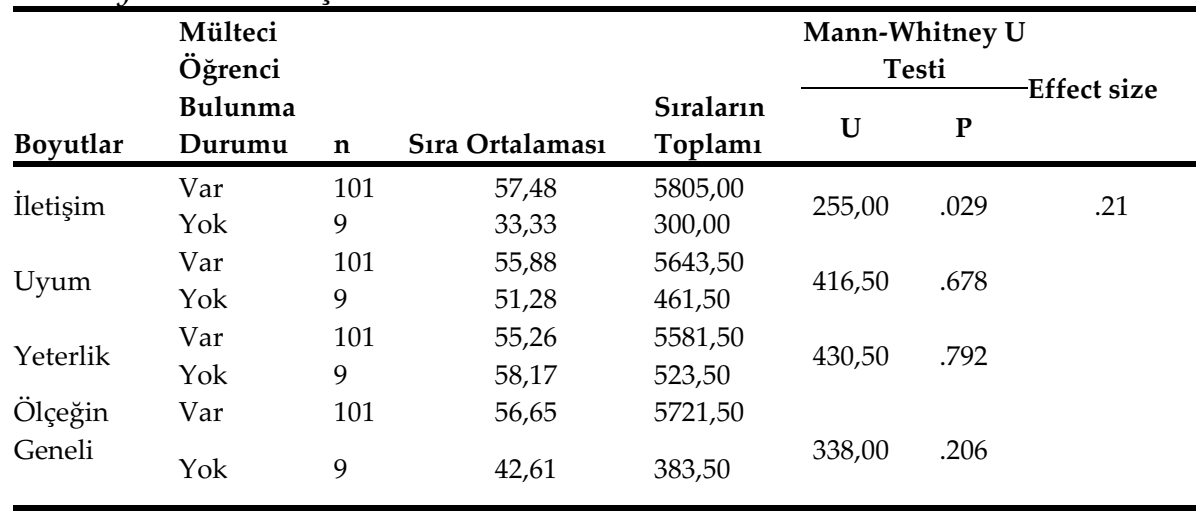

Son olarak, araştırmaya katılan öğretmenlerin mülteci öğrencilere ilişkin herhangi bir eğitim (kurs, seminer, hizmet içi eğitim) alma durumlarına göre tutumlarında farklılaşma olup olmadığ incelenmiştir. Bu amaçla yapılan Mann Whitney $U$ testi sonuçları aşağıdaki tabloda gösterilmiştir.

Tablo 10. Öğretmenlerin Mülteci Öğrencilere Yönelik Eğitim Alma Durumlarn Açısından Mülteci Öğrencilere Yönelik Tutumlarının Karşılaştırılmasına İlişkin Mann Whitney U Testi Sonuçları

\begin{tabular}{|c|c|c|c|c|c|c|}
\hline \multirow[b]{2}{*}{ Boyutlar } & \multirow{2}{*}{$\begin{array}{l}\text { Mülteci Öğren- } \\
\text { cilere Yönelik } \\
\text { Eğitim Alma } \\
\text { Durumu }\end{array}$} & \multirow[b]{2}{*}{$\mathbf{n}$} & \multirow[b]{2}{*}{$\begin{array}{l}\text { Sira } \\
\text { Ortalaması }\end{array}$} & \multirow[b]{2}{*}{$\begin{array}{l}\text { Siraların } \\
\text { Toplamı }\end{array}$} & \multicolumn{2}{|c|}{$\begin{array}{c}\text { Mann-Whitney U } \\
\text { Testi } \\
\end{array}$} \\
\hline & & & & & $\mathbf{U}$ & $\mathbf{P}$ \\
\hline \multirow{2}{*}{ İletişim } & Evet & 59 & 57,97 & 3420,50 & \multirow{2}{*}{1358,50} & \multirow{2}{*}{.380} \\
\hline & Hayır & 51 & 52,64 & 2684,50 & & \\
\hline \multirow{2}{*}{ Uyum } & Evet & 59 & 57,66 & 3402,00 & \multirow{2}{*}{1377,00} & \multirow{2}{*}{.443} \\
\hline & Hayır & 51 & 53,00 & 2703,00 & & \\
\hline \multirow{2}{*}{ Yeterlik } & Evet & 59 & 56,05 & 3307,00 & \multirow{2}{*}{1472,00} & \multirow{2}{*}{.845} \\
\hline & Hayır & 51 & 54,86 & 2798,00 & & \\
\hline \multirow{2}{*}{$\begin{array}{l}\text { Ölçeğin } \\
\text { Geneli }\end{array}$} & Evet & 59 & 57,90 & 3416,00 & \multirow{2}{*}{1363,00} & \multirow{2}{*}{.396} \\
\hline & Hayır & 51 & 52,73 & 2689,00 & & \\
\hline
\end{tabular}

Tablo 10 'da, öğretmenlerin mülteci öğrencilere yönelik eğitim alıp almama durumlarına göre tutumlarının iletişim $(U=1358,50 ; p>, 05)$, uyum $(U=1377,00 ; p>, 05)$, yeterlik $(U=1472,00 ; p>, 05)$ alt boyutlarında 
ve ölçeğin genelinde $(U=1363,00 ; \mathrm{p}>, 05)$ anlamlı bir şekilde farklılaşmadığı görülmektedir.

\section{Sonuç, Tartışma ve Öneriler}

Bu çalışmada ulaşılan sonuçlara göre; mülteci öğrencilere yönelik öğretmen tutumlarının uyum, yeterlik alt boyutlarında ve ölçeğin genelinde katılıyorum, iletişim alt boyutunda ise tamamen katılıyorum düzeyinde olduğu görülmüştür. Ayrıca, öğretmenlerin mülteci öğrencilere ilişkin tutumlarının iletişim alt boyutunda yüksek, uyum ve yeterlik alt boyutlarında ve ölçeğin genelinde ise kabul edilebilir düzeyde olduğu sonucuna ulaşılmıştır. Bu sonuç öğretmenlerin mülteci öğrencilerle iletişim boyutunda güçlük yaşamadığı; ancak, bu öğrencilerin eğitim ortamına entegre edilmelerinde yeterlilik ihtiyaçlarının olduğu şeklinde yorumlanabilir. Mülteci öğrencilere yönelik öğretmen tutumlarının belirlenmeye çalışıldığı ve bu öğrencilerin devam ettiği okullarda karşılaşılan sorunların ele alındığı çalışmalarda da benzer sonuçlara ulaşılmıştır. Gülüm ve Akçalı'nın (2017) ulaştıkları araştırma sonuçlarına göre, öğretmenlerin mülteci öğrencilere karşı olumlu tutum sergiledikleri saptanmıştır. Sağlam ve Kanbur (2017) tarafından yapılan araştırmada, öğretmenlerin mülteci öğrencilere yönelik tutumlarının yeterlilikten etkilendiği sonucuna ulaşılmıştır. Şimşir ve Dilmaç (2018) mülteci öğrencilerin bulunduğu eğitim ortamlarında öğretmenlerin dil ve iletişim problemlerinin yanı sıra, sosyal ve akademik problemler yaşadıklarını tespit etmişlerdir. Martín-Pastör vd. (2013) yaptıkları çalışmada, mülteci öğrencilerin yaşadıkları akademik güçlüklerin kültürel farklılıklardan ve öğretmen yaklaşımlarından kaynaklanabileceği belirtilmektedir. Mülteci öğrencilerin Türk eğitim sistemi ve okul kültürüne uyumu ile ilgili durumlarını tespit etmek amaciyla Tosun vd. (2018) tarafından gerçekleştirilen araştırma bulguları, bu öğrencilerin dil ve kültür uyuşmazlığı nedeniyle çeşitli zorluklar yaşadıklarını; olumlu okul iklimi, destekleyici öğretmen tutumları ve aktiviteler sağlandığında ise uyum süreçlerinin hızlandığına işaret etmektedir. Aynı çalışmada öğretmen eğitimlerinin güçlendirilmesi gerektiği de ifade edilmektedir. Benzer şekilde, Fisher vd. (2000) tarafından yapılan araştırmada, mülteci öğrencilere yönelik olumsuz tutum ve önyargıların önüne geçebilmek ve 
uyum sürecini hızlandırmak için, öğretmenler tarafından kültürel anlayışı destekleyici ve etkileşimi artırıcı etkinliklerin organize edilmesi gerektiği belirtilmektedir.

$\mathrm{Bu}$ araştırmada elde edilen sonuçlar, öğretmenlerin mülteci öğrencilere ilişkin tutumlarının cinsiyet açısından bütün alt boyutlarda anlamlı düzeyde farklılaşmadığını göstermektedir. Daha önce yapılan bir çalışmada (Sağlam ve Kanbur, 2017) ise, sadece yeterlik alt boyutunda erkek öğretmenlerin lehine anlamlı bir farklılık görülmüştür. Ulaşılan bu sonuçlar, hem kadın hem de erkek öğretmenlerin iletişim, uyum ve yeterlik bakımından mülteci öğrencilere yönelik birbirine yakın düzeyde tutuma sahip oldukları şeklinde yorumlanabilir.

Kıdem değişkeni açısından elde edilen bulgulara göre yeterlik alt boyutu dışında, iletişim, uyum ve ölçeğin genelinde öğretmenlerin mülteci öğrencilere yönelik tutumlarında anlamlı farklılıklar olmadığı sonucuna ulaşılmıştır. Bu sonuç, kıdem alt boyutu puanının yüksek olmasının, yeterlik boyutunu olumlu yönde etkilediği şeklinde yorumlanabilir. Kağıtçıbaşı'na (2008) göre, bir objeye karşı olumlu tutum oluşmasının en önemli nedenlerinden biri o objeyle yaşanan doğrudan deneyimlerdir. Benzer şekilde, Bandura (1997) yeterlik inançlarının oluşumunda kişinin kendi deneyimlediği performans başarılarının önemine değinmektedir. Erdem vd. (2017) tarafından yapılan ve mülteci öğrencilere yönelik öğretmen görüşlerinin belirlenmeye çalışıldığ araştırmada, mülteci öğrencilerin eğitiminde birtakım problemlerin yaşandığı ve bunlardan öne çıkanların; öğrencilerin okul yaşantıları, uyum problemleri, iletişim ve dil sorunları olduğu ve bunların öğretmen yeterlikleri ile ilişkili olduğu sonucuna ulaşılmıştır. Dolayısıyla, mülteci öğrencilerin eğitiminde karşılaşılan zorluklar (dil problem, uyum ve akademik güçlükler) dikkate alındığında, öğretmen yeterliliğinin bu süreçteki önemi bir kez daha ortaya çıkmaktadır. Nitekim, Li (2003) ve Windle ve Miller (2012) tarafından yapılan çalışma sonuçları bunu doğrular niteliktedir. Anılan çalışmalarda, öğretmen yeterliliği, öğretim becerileri, dil becerileri ve kültürel yaklaşımlarının istenilen düzeyde olmamasının öğrencilerde olumsuz öğrenme yaşantılarına neden olduğu sonucuna ulaşılmıştır. Bu sonuçlar mülteci öğrencilere sunulacak eğitim hizmetleri açısından değerlendirildiğinde, öğretmen yeterliklerinin öğrenci uyumu üzerinde etkili olduğu; uyum sürecini hızlandıran etkin- 
lik ya da uygulamaların teşvik edilmesi gerektiğini ortaya koymaktadır. Sonuç olarak, bu araştırmada ulaşılan ve yüksek deneyimin yeterlik üzerindeki olumlu etkisini içeren araştırma sonucundan hareketle, deneyimi yüksek olan öğretmenlerin bu öğrencilerin eğitim hizmetlerinde öncelikli olarak görevlendirilmeleri gerektiği söylenebilir

Katılımcıların sınıf ya da diğer branş öğretmeni olma durumlarına göre mülteci öğrencilere ilişkin tutumlarının, iletişim alt boyutu ve ölçeğin genelinde sınıf öğretmenleri lehine farklılaştığı; uyum ve yeterlik alt boyutlarında ise anlamlı bir şekilde farklılaşmadığı görülmüştür. Bu sonuç, sınıf öğretmenlerinin diğer branş öğretmenlerine kıyasla mülteci öğrencilerle daha iyi anlaştığı, iletişim kurduğu ve uyum sağladıkları şeklinde yorumlanabilir. Aslan ve Kozikoğlu (2017) tarafından yapılan araştırmada ise, sınıf öğretmenleri başta olmak üzere, psikolojik danışmanlar, özel eğitim öğretmenleri ve Türk dili ve edebiyatı öğretmenlerinin de mülteci öğrencilere yönelik güçlü tutuma sahip oldukları tespit edilmiştir. Diğer taraftan, Er ve Bayındır (2015), sınıf öğretmenlerinin bu öğrencilerin eğitimi ile ilgili herhangi bir eğitimlerinin olmadığını tespit etmiştir. Mülteci öğrencilerin okul ortamına uyum sağlaması ile ilgili sınıf öğretmenlerinin yeterli düzeyde eğitimlerinin olmadığı halde, bu öğrencilere yönelik tutumlarının diğer branş öğretmenlerine göre yüksek olması; öğrenci gelişim özelliklerinin farklı olması, sınıf ve diğer branş öğretmenlerinin uzmanlık alanlarının farklı dinamiklere sahip olması ve öğrenme-öğretme ortamlarının farklı olmasından kaynaklı olabileceği düşünülmektedir.

$\mathrm{Bu}$ çalışmada elde edilen diğer bir sonuç ise, öğretmenlerin öğrenim düzeyi değişkenine göre mülteci öğrencilere yönelik tutumlarının tüm alt boyutlarda anlamlı bir şekilde farklılaşmadığıdır. Lisans ve lisansüstü eğitim düzeyine sahip öğretmenlerin mülteci öğrencilere yönelik tutumları açısından bir farklılık olmaması, öğretmenlerin lisans ve lisansüstü düzeyinde mülteci öğrencilerle ilgili herhangi bir eğitim almaması ile açıklanabilir. Kapsayıcı eğitimin etkili olarak uygulanmasının öğretmen yeterliliği ve olumlu öğretmen yaklaşımları yakın ilişkisi göz önüne alındığında, elde edilen bu sonucun öğretmen eğitimleri ile ilgili yaşanan güçlüklerin belirtisi olabileceği düşünülmektedir. Bu bulgulara benzer olarak Erdem (2017), Bulut vd. (2018), Taşkın ve Erdemli (2018) tarafından yapılan araştırmalarda, öğretmenlerin mülteci öğrencilerin 
eğitiminde büyük zorluklar yaşadıkları ve mesleki gelişim ihtiyacı içerisinde oldukları saptanmıştır. Benzer şekilde, Dooley ve Thangaperumal (2011) ve Şeker ve Sirkeci (2015) tarafından yapılan çalışmalarda, öğretmenlerin geleneksel pedagojik teknikleri sıklıkla kullandıkları ve buna bağlı olarak mülteci öğrencilerin akademik becerilerinin gelişiminde zorluklar yaşandığı bulgusuna ulaşılmıştır. Dooley (2009) ve MacNevin (2012) ise, öğretmenlerin pedagojik repertuarlarını genişletmelerinin önemine değinmektedir. Araştırma sonuçları öğretmenlerin hizmet öncesi ve hizmet sırasında mülteci öğrencilerle ilgili sıklıkla eğitim almalarının önemini vurgular niteliktedir. Öğretmenleri hizmet içi eğitim faaliyetleri ile destekleyen MEB'in, mülteci öğrencilere yönelik öğretmen el kitapları ve kılavuz kaynaklar hazırlamak ve dağıtımını gerçekleştirmekle, kapsayıcı eğitim ile ilgili öğretmenlerin yaşadığı güçlükleri azaltmayı hedeflediği söylenebilir. Sınıflarında mülteci öğrenci bulunma değişkenine göre öğretmen tutumları incelendiğinde; uyum ve yeterlik alt boyutu ile ölçeğin genelinde anlamlı bir farklılaşmanın olmadığı; iletişim alt boyutunda ise sınıfında mülteci öğrenci olan öğretmenlerin lehine anlamlı bir farklılaşmanın olduğu sonucuna ulaşılmıştır. Araştırmaya katılan öğretmenlerin \%92'sinin görevli olduğu eğitim ortamlarında mülteci öğrenci bulunduğu göz önüne alındığında, elde edilen sonuçların arzu edilenden düşük olduğu söylenebilir. Bu açıdan araştırmanın bulgularının tamamen olmasa bile Sağlam ve Kanbur'un (2017) çalışmasında elde edilen sonuçları desteklediği söylenebilir. Sınıflarında mülteci öğrenci bulunan öğretmenlerin, bu öğrencileri yakından tanıdığı ve gereksinimlerini hızlı bir şekilde farkettikleri söylenebilir. Çok kültürlü eğitimin giderek yaygınlaştığı günümüzde, öğretmenlerin farklı kültürel özelliklere sahip öğrencilerle empati kurmaları beklenmektedir. Fisher vd. (2000) tarafından yapılan araştırmada, mülteci öğrencilere yönelik olumsuz tutum ve önyargıların önüne geçebilmek için, kültürel anlayışı destekleyici ve etkileşimi artırıcı anlayışın benimsenmesi gerektiği belirtilmektedir. Mülteci öğrencilere yönelik eğitim alma durumu değişkenine göre öğretmen tutumları incelendiğinde; tüm alt boyutlarda anlamlı bir farklılaşma olmadığı görülmüştür. Elde edilen bu sonuç, mülteci öğrenciler ile ilgili eğitim (seminer, kurs, hizmet içi eğitim vb.) alan öğretmenlerin herhangi bir eğitim almayan öğretmenlere göre mülteci öğrencilere 
yönelik tutumlarında bir farklılaşma oluşturmadığını göstermektedir. Bu durum öğrencilere yönelik sunulan eğitim hizmetlerinin uyarlanmış kazanımlar içermemesi, post travmatik süreçlerle ilgili profesyonel destek eğitimlerin gerçekleştirilememesi, öğretmenlere yönelik süpervizyon hizmetlerin yetersiz olması ve düzenlenen eğitimlerin teorik hizmet içi eğitimler ile sınırlı kalması ile açıklanabilir. Diğer taraftan, bu sonucun, kapsayıcı eğitim kapsamında MEB tarafından yürütülen hizmet içi eğitim faaliyetlerinin hedeflediği olumlu öğretmen tutumlarının gelişimi, öğretim becerilerinin çeşitlendirilmesi ve çok kültürlü eğitim ortamlarının zenginleştirilmesi beklentisiyle uyuşmadığ 1 da söylenebilir. Kirk (2007), mülteci öğrencilere yönelik sunulacak eğitim için gereken minimum standartları; (1) toplum, (2) erişim, (3) öğrenme, (4) eğitim personeli ve (5) koordinasyon şeklinde sıralamaktadır. UNHCR (The UN Refugee Agency) (2001, s.1) ise, mülteci öğrencilerin eğitiminde olumlu öğretmen yaklaşımlarının temel unsur olduğunu vurgulamaktadır. Bu bağlamda, ülkemizde mülteci öğrencilerin eğitime entegrasyonunu sağlamak amacıyla öğretmenlere hizmet öncesi ve hizmet sırasında sunulan eğitimlerin, istenilen standartlara erişilmesini sağlayacak düzeyde olmadığı söylenebilir. Balkar vd. (2016) ve Er ve Bayırdır (2015) tarafından yapılan araştırma sonuçlarında, mülteci öğrenci eğitiminde hedeflenen standartlara ulaşmada hizmet içi eğitimlerin niteliği ve mesleki gelişimdeki önemine vurgu yapılmıştır.

Araştırmanın sonuçlarına dayalı olarak şu öneriler sunulmuştur:

- Mülteci öğrencilerin eğitim durumlarını (iletişim güçlüğü, akademik başarısızlık vb.) etkileyen yöneticiler, öğrenciler ve ailelerle benzer çalışmalar yapılabilir.

- Kapsayıcı eğitim kapsamında mülteci öğrencilerin eğitimine dönük düzenlenen hizmet içi eğitim faaliyetlerinin, etkililiği bilimsel olarak kanıtlanmış uygulamalara dönüşmesi gerekmektedir.

- Mülteci öğrencilerin sınıf ve okul ortamına uyum sağlamaları, olumlu öğretmen tutumlarıyla yakından ilişkili olduğu düşünüldüğünde; bu öğrencilerin sosyal ve kültürel özellikleri ve akademik becerilerini geliştirmeyi amaçlayan ve öğretmenlerin uygulamalarına kaynaklık edebilecek, deneysel olarak sınanmış öğretim programları hazırlanabilir. 
- Öğretmenlere hizmet öncesinde, mülteci öğrencileri doğrudan etkileyen kapsayıcı eğitim, çok kültürlülük ve destekleyici okul iklimi ile ilgili eğitimler verilmelidir.

- Mülteci öğrencilerin eğitiminde mesleki deneyimi yüksek olan öğretmenlerin anahtar rollerde görevlendirilmesine dikkat edilmelidir.

- Farklı illerde görev yapan öğretmenlerle benzer araştırmalar yapılması elde edilen sonuçların zenginleşmesini ve sonuçların karşılaştırılmasını sağlayacaktır. 


\title{
EXTENDED ABSTRACT
}

\section{An Examination of the Teachers' Attitudes Towards The Refugee Students in Terms of Various Variables Within the Scope of Inclusive Education}

\author{
Hilal Kazu - Emrullah Deniz \\ Furat University
}

Individuals leave their places where they live and try to shelter into new living spaces due to war, social events, and natural disaster of other reasons. This process which is dragged by the life instinct causes the individuals to meet the fact of immigration. Besides the traumatic processes which are encountered by the people who are dragged along by the immigration, health and sheltering problems, harmonization problems which are brought along by the new living spaces both come to forefront as new challenges. The formation of the majority of the refugees from the children with young ages reveals the significance of the psychological processes which are experienced by these people (Ferris and Winthrop, 2010, p.29; Yavuz and Mizrak, 2016).

Besides the health, care services which are affected by the immigration, education is interrupted as well. Considering the fact that the education develops the refugee students' coherence skills with their fellows (UNESCO, 2006; Ferris and Winthrop, 2010) and their skills to handle the challenges (Mackinnon, 2014), it may be expressed that the sustainability of the education should be provided. Moreover, interruption of the education shall lead to the failure of the educational rights of the individuals which are being protected by the laws (Pigozzi, 1999). On the other hand, states which are aware of that the education is an inevitable factor for the refugee students execute various legal arrangements, policies and applications regarding these students' access to education. It is hereby desired that the educational services presented to the refugee students should aim to alleviate the cultural differences and to establish a com- 
mon cultural basis. For this purpose, various standards are being attempted to be formed. According to INEE (Inter-Agency Network for Education in Emergencies) (2010) which represents one of these approaches; the educational standards; (a) should respect to human rights and should be in such a manner to protect these rights, (b) should provide the students to be capable of overcoming the negative life being experienced, (c) should enable easy and free transportation, (d) and these standards should be executed by competent people who are aware of the necessities of the students.

In our country, in terms of 12 June 2019, 3.606.737 Syrian people are living; and $46 \%$ of this population consists of young people between $0-18$ age range (URL 1). For the students which comprise the majority of the refugee population in our country, an inclusive education is implemented. According to UNESCO (2005, p.13), inclusive training is defined as; "the replying process against the learners' various necessities, by increasing their participation into education, culture and society and by decreasing the discrimination within the education". From this aspect, it can be expressed that the inclusive training aims to make the refugee students integrated with the education system as quick as possible. Besides, it is also aimed that; teachers should adopt student variety, should act against the students without discrimination, should be aware of the necessities of the students, and should be capable of making adaptations into the learning areas accordingly. Refugee students' orientation with the educational environment, their academic performances and positive sense of self are closely related to the teachers' attitudes. Based on this fact, the general purpose of this study is to examine the attitudes of the teachers who are charged at various stages against refugee students. 


\section{Method}

The model of the research consist of a relational and descriptive survey models. In relational survey models, the differentiation among the groups are examined according to the specified variables (Karasar, 2005, p.81). In the descriptive research model, the cases are tried to be defined as much as possible (Büyüköztürk et al., 2013, p.24). The study group of the research consists of totally 110 (60 female, 50 male) teachers who are assigned in various stages of the education in a province in Southeastern Anatolia attended into the survey which was conducted in 2018-2019 academic year. $26,4 \%$ (29) of the teachers who participated into the research consist of class teachers whereas $73,6 \%$ of them consist of branch teachers. It was determined that the teachers whose classes include refugee students consisted $91,8 \%$ (101) of the total attendants whereas $8,2 \%$ of the teachers had no refugee students in their classes. Besides, 53,6\% (59) of the teachers have received training relevant with refugee students (course, seminar etc.) whereas $46,4 \%$ of them have not received any training thereof.

In the study, in order to determine the teachers' attitudes against the refugee students, Refugee Student Attitude Scale (МÖTÖ)- developed by Sağlam and Kanbur (2017) was used. The scale which has 4 Likert type grading consists of three dimensions (communication, coherence, competence) and 24 items totally. As the distribution variances have not been distributed normal in all independent variables, tests which do not require normality tests were used in data analysis. For this purpose; Mann Whitney $U$ test was used in order to examine the teachers' attitude against refugee students in terms of their gender, professional seniority, their situation for being class or branch teacher, education status, the existence of refugee students in their classes and receiving education related with refugee students. On the other hand, Kruskall Wallis $\mathrm{H}$ test 
was used to make an examination according to their professional seniority situations. Analysis results were assessed at $\mathrm{p}<.05$ significance level.

\section{Results}

According to the results obtained in this study; it was seen that; the teachers' attitudes towards refugee students are at I agree level in coherence, competence sub-dimensions and in the scale as a whole, whereas it was at $I$ do not agree level in communication sub-dimension. These results reveal that the teachers' attitudes regarding refugee students are at higher level in communication sub-dimension and at acceptable level in coherence and competence sub-dimensions. This result can be explained by non-existence of satisfactory training for refugee students, non- existence of preparatory training for multicultural structure based training environments, as well as by coherence problems with students and existence of communication difficulty. These results resemble with the findings obtained in the studies in which the teachers' attitudes were aimed to be determined against the refuge students (Sağlam and Kanbur 2017) and in the studies where challenges of the students in the relevant schools are discussed (Li, 2003; Windle and Miller, 2012; Erdem et al., 2017). Martín-Pastör et al. (2013); in their studies, state that; academic difficulties encountered by the refugee students might born from cultural differences. Findings obtained in this study reveal that teachers' attitudes towards the refugee students do not become different significantly in all sub-dimensions in terms of gender. Except the competence subdimension in terms of professional seniority, within the generality of communication, coherence and scale, it is found that no significant variation occurs in the teachers' attitudes towards refugee students. This result of the research is also supported by Erdem et al. (2017), in their research. As mentioned by Bandura (1997), in the formation of competence belief person's performance achievements are very important. From this 
point of view, teachers with higher professional experiences are expected to be appointed primarily in the training services for these students.

It is hereby seen that; the attitudes of the teachers towards the refugee students according to the participants' being class or branch teacher have become different in favor of class teachers in communication sub- dimension and in the generality of the scale; but no significant differentiation has been observed in coherence and competence sub-dimensions. This result may be interpreted in such a manner that class teachers get on well with refugee students better than the branch teachers, they communicate and accord better. Another result obtained in this study is that; teachers' attitude towards refugee students according to their education level variable reveals no significant differentiation in all sub-dimensions. This can be explained in such a manner that; teachers have not received any training about refugee students either in bachelor's degree or postgraduate level. Similar with these findings, Dooley (2009), Dooley and Thangaperumal (2011), MacNevin (2012), Şeker and Sirkeci (2015), Erdem (2017), Bulut et al. (2018), Taşkın and Erdemli (2018); displayed in their studies that; teachers have been in difficulty for the training of the refugee students and they need professional development. When the teachers' attitudes are examined according to the existence of refugee students in their classes; it is seen that; no significant differentiation exists in coherence and competence sub-dimensions and in the generality of the scale; but a significant differentiation has been observed in favor of the teachers who have refuge students in their classes in the communication sub-dimension. When the teachers' attitudes are examined according to the teachers' status of training on refugee students; no significant differentiation has been observed in all sub-dimensions. This can be explained in such a manner that; the training services submitted to the students include no adopted earnings, non-existence of professional support trainings on post-traumatic processes, non-existence of supervision 
services for the teachers, and the trainings submitted to the students have been limited by theoretical in-service training.

Results of the research reveal that; training of the teachers should be based on application within the scope of inclusive training, multicultural training applications should be expanded, events towards the students which accelerate the adoption process should be increased, adaptations should be provided in teaching programs, and attention should be paid to the assignment of experienced teachers in key roles in the education of refugee students.

\section{Kaynakça / References}

Alharbi, B.H.M. (2017). Psychological security and self-efficacy among Syrian refugee students inside and outside the camps. Journal of International Education Research, 13(2), 59-68.

Aslan, M. ve Kozikoğlu, İ. (2017). Öğretmenlerin çok kültürlü eğitime yönelik tutumları: Van ili örneği. Dicle Üniversitesi Ziya Gökalp Eğitim Fakültesi Dergisi, 31, 729-737.

Bandura, A. (1977). Self-efficacy: Toward a unifying theory of behavioral change. Psychological Review, 84, 191-215.

Balkar, B., Şahin, S. ve Işıklı Babahan, N. (2016). Geçici eğitim merkezlerinde (GEM) görev yapan Suriyeli öğretmenlerin karşılaştıkları sorunlar. Eğitimde Kuram ve Uygulama, 12(6), 1290-1310.

Baltacı, H. (2014). Göçmen öğrencilerin başarı durumunu etkileyen etmenlerin okul yöneticisi, öğretmen, veli ve öğrencilerin görüşlerine göre değerlendirilmesi. Yayımlanmamış yüksek lisans tezi, Yakın Doğu Üniversitesi, Eğitim Bilimleri Enstitüsü, Kıbrıs.

Başar, M., Akan, D. ve Çiftçi, M. (2018). Mülteci öğrencilerin bulunduğu sınıflarda öğrenme sürecinde karşılaşılan sorunlar. Kastamonu Education Journal, 26(5), 1571-1578.

Bouton, B. (2016). Understanding the unique needs of adolescent refugee students. Middle Grades Review, 3(2), 1-6.

Börü, N. ve Boyacı, A. (2016). Göçmen öğrencilerin eğitim-öğretim ortamlarında karşılaştıkları sorunlar: Eskişehir ili örneği. Electronic Turkish Studies, 11(14), 123-158. 
Bulut, S., Soysal, Ö.K. ve Gülçiçek, D. (2018). Suriyeli öğrencilerin Türkçe öğretmeni olmak: Suriyeli öğrencilerin eğitiminde karşılaşılan sorunlar. Uluslararası Türkçe Edebiyat Kültür Eğitim Dergisi, 7(2), 12101238.

Büyüköztürk, Ş., Kılıç Çakmak, E., Akgün, Ö. E., Karadeniz, Ş. ve Demirel, F. (2013). Bilimsel araştırma yöntemleri. Ankara: Pegem A Yayıncllık.

Cohen, J.W. (1988). Statistical power analysis for the behavioral sciences. New York: Lawrence Erlbaum Associates, Publishers.

Croce, K.A. (2018). Refugee students arrive at a school: What happens next?. Global Education Review, 5(4), 7-16.

Dooley, Karen T. (2009). Re-thinking pedagogy for middle school students with little, no or severely interrupted schooling. English Teaching : Practice and Critique, 8(1), 5-22.

Dooley, Karen T. ve Thangaperumal, P. (2011). Pedagogy and participation: Literacy education for low-literate refugee students of African origin in a western school system. Language and Education. (In Press).

Er, A. R. ve Bayındır, N. (2015). İlkokula giden mülteci çocuklara yönelik sınıf öğretmenlerinin pedagojik yaklaşımları. Uluslararası Sosyal ve Eğitim Bilimleri Dergisi, 2(4), 175-185.

Erdem, C. (2017). Sınıfında mülteci öğrenci bulunan sınıf öğretmenlerinin yaşadıkları öğretimsel sorunlar ve çözüme dair önerileri. Medeniyet Ĕ̆itim Araştırmaları Dergisi, 1(1), 26-42.

Erdem, M.D., Kaya, İ. ve Yılmaz, A. (2017). Örgün eğitim kapsamındaki Suriyeli çocukların eğitimleri ve okul yaşantıları hakkında öğretmen görüşlerinin değerlendirilmesi. International Journal of Languages' Education and Teaching, 3(5), 463-476.

Ferris, E. ve Winthrop, R. (2010). Education and displacement: Assessing conditions for refugees and internally displaced persons affected by conflict. UNESCO.

Fisher, C.B., Wallace, S.A. ve Fenton, R.E. (2000). Discrimination distress during adolescence. Journal of Youth and Adolescence, 29(6), 679-695.

Göç İdaresi Genel Müdürlüğü (GİGM) (2016). Geçici korumamız altındaki Suriyeliler. 20.06.2019 tarihinde http://www.goc.gov.tr/ icerik3/gecicikorumamiz-altindaki-suriyeliler 409558560 adresinden erişildi.

Gömleksiz, M.N. ve Aslan, S. (2018). The views of secondary school teachers about refugee students. Education Reform Journal, 3(1), 32-44. 
Gülüm, K. ve Akçalı, H. (2017). Balıkesir'deki mülteci çocukların eğitim sorunları. Yüzüncü Yıl Üniversitesi Sosyal Bilimler Enstitüsü, 1(1), 127136.

Güngör, F. ve Şenel, E.A. (2018). Yabancı uyruklu ilkokul öğrencilerinin eğitim-öğretiminde yaşanan sorunlara ilişkin öğretmen ve öğrenci görüşleri. Anadolu Journal of Educational Sciences International, 8(2), 124-173.

INEE (2010). http://www.ineesite.org/en/minimum-standards/handbook, Erişim Tarihi: 11.06.2019.

Kağıtçıbaşı, Ç. (2008). Günümüzde insan ve insanlar: Sosyal psikolojiye giriş. İstanbul: Evrim.

Karasar, N. (2005). Bilimsel araştırma yöntemleri. Ankara: Nobel Yayın Dağıtım.

Kiremit Filiz, R., Akpınar, Ü. ve Tüfekci Akcan, A. (2018). Suriyeli öğrencilerin okula uyumları hakkında öğretmen görüşleri. Kastamonu Eğitim Dergisi, 26(6), 2139-2149.

Kirk, J. ve Cassity, E. (2007). Minimum standards for quality education for refugee youth. Youth Studies Australia, 26(1), 50-56.

Kuzu Jafari, K., Tonga, N. ve Kışla, H. (2018). Suriyeli öğrencilerin bulunduğu sinıflarda görev yapan sinıf öğretmenlerinin görüşleri ve uygulamaları. Academy Journal of Educational Sciences, 2(2), 134-146.

Li, M. (2003). Culture and classroom communication: A case study of Asian students in New Zealand language schools. The joint NZARE-AARE Conference, Hyatt Regency Hotel \& University of Auckland, New Zealand. Retrieved May 19, 2019.

Mackinnon, H. (2014). Education in emergencies: The case of the Dadaab refugees camp. Policy Brief, 47, 1-12.

MacNevin, J. (2012). Learning the way: Teaching and learning with and foryouth from refugee backgrounds on Prince Edward Island. Canadian Journal of Education, 35(3), 46-63.

McParker, M.C. (2018). Experiences of female refugee students from Burma in multicultural middle school classrooms. Middle Grades Review, (2), 4, 1-18.

Martín-Pastor, E., Gönzález-Gil, F., Río, C. J., Röbaina, N. F., ve Castro, R. P. (2013). Influence of immigrant students' communication skills on their teaching and learning process. Procedia-Socialand Behavioral Sciences, 93, 789-793. 
MEB (2018). Kapsayıcı eğitim projesi, https://oygm.meb.gov.tr/www/kapsayici-egitim-projesi-inclusive-education/icerik/679 Erişim Tarihi: 03.06.2019.

Mercan Uzun, E. M. ve Bütün, E. (2016). Okul öncesi eğitim kurumlarındaki Suriyeli sığınmacı çocukların karşılaştıkları sorunlar hakkında öğretmen görüşleri. Uluslararası Erken Çocukluk Eğitimi Çalışmaları Dergisi, 1(1), 72-83.

Miller, J., Mitchell, J. ve Brown J. (2005). African refugees with interrupted schooling in the high school mainstream: Dilemmas for teachers. Prosoect, 20(2), 19-33.

Öztürk Zayimoğlu, F. (2018). Mülteci öğrencilere sunulan eğitim-öğretim hizmetinin sosyal bilgiler öğretmen görüşlerine göre değerlendirilmesi. Anadolu Journal of Educational Sciences International, 8(1), 52-79.

Öztürk, M., Tepetaş Cengiz, G.Ş., Köksal, H. ve İrez, S. (2017). Sinıfinda yabancı uyruklu öğrenci bulunan öğretmenler için el kitabı. (Ed.: Semih Aytekin). Ankara: MEB Yayınları.

Özer, Y. Y., Komsuoğlu, A. ve Ateşok, Z. Ö. (2016). Türkiye'deki Suriyeli çocukların eğitimi: Sorunlar ve çözüm önerileri. Akademik Sosyal Araştırmalar Dergisi, 4(37), 76-110.

Pallant, J. (2016). SPSS kullanma kılavuzu: Spss ile adım adım veri analizi. Balc1, S. ve Ahi, B. (Çev.). Ankara: Anı Yayınları.

Patton, M. Q. (2002). Qualitative research evulation methods. California: SAGE Publications.

Pigozzi, M. J. (1999). Education in emergencies and for reconstruction: A developmental approach. New York: United Nations Children's Fund Working Paper Series.

Sinclair, M. (2007). Education in emergencies: Common wealth education partnerships 2007. Nexus Strategic Partnerships, 52-56.

Şeker, B. D. ve Arslan Z. (2015). Eğitim sürecinde mülteci çocuklar: Sosyal psikolojik bir değerlendirme. Kuramsal Eğitim Bilim Dergisi, 8(1), 86105.

Şeker, B. D. ve Sirkeci, I. (2015). Challenges for refugee children at school in Eastern Turkey. Economics and Sociology, 8(4), 122-133.

Şimşir, Z. ve Dilmaç, B. (2018). Yabancı uyruklu öğrencilerin eğitim gördüğü okullarda öğretmenlerin karşılaştığı sorunlar ve çözüm önerileri. Ilköğretim Online, 17(2), 1116-1134. 
Taşkın, P., ve Erdemli, O. (2018). Suriyeli öğrencilerin eğitimi: Türkiye'de öğretmenlerin karşılaştığı sorunlar. Eurasian Journal of Educational Research, 75, 155-178.

Tabachnick, B.G. ve Fidell, L.S. (2015). Çok değişkenli istatistiklerin kullanımı. Baloğlu, M. (Çev.). Ankara: Nobel Yayınları.

Talbot, C. (2013). Education in conflict emergencies in light of the post-2015 $M D G s$ and EFA Agendas. Switzerland: NORRAG.

Tomczak, M. ve Tomczak, E. (2014). The need to report effect size estimates revisited. An overview of some recommended measures of effect size. Trends in Sport Sciences, 1(21), 19-25.

Tosun, A., Yorulmaz, A., Tekin, İ. ve Yıldız, K. (2018). Mülteci öğrencilerin eğitim sorunları, eğitim ve din eğitiminden beklentileri: Eskişehir örneği. Eskişehir Osmangazi Üniversitesi Sosyal Bilimler Dergisi, 19(1), 107-133.

Türmen, T. (2012). Afet zamanlarında eğitim: Eğitim izleme raporu. İstanbul: Eğitim Reformu Girişimi (ERG).

URL-1 (2019). 10.05.2019 tarihinde http://www.goc.gov.tr adresinden erişildi.

UNESCO (2005). Guidelines for inclusion: Ensuring access to education for all. 10.05.2019 tarihinde https://unesdoc.unesco.org/ark:/48223/ pf0000140224 adresinden erişildi.

UNESCO (2006). Education in emergencies: The gender implications- advocacy Brief. 12.05.2019 tarihinde https://unesdoc.unesco.org/ark: /48223/ pf0000148908 adresinden erişildi.

UNHCR (2001). Learning for a future: Refugee education in developing countries. 19.05.2019 tarihinde https://www.unhcr.org/4a1d5ba36.pdf adresinden erişildi.

UNICEF (2009). Policy guidelines on inclusion in education. 20.06.2019 tarihinde http://www.edchreturkeyeu.coe.int/Source/Resources Policy Guidelines on inclusion in education EN.pdf adresinden erişildi.

UNICEF (2016). Türkiye'deki Suriyeli mülteciler bilgi notu. 20.06.2019 tarihinde http://unicef.org.tr/files/bilgimerkezi/doc/T\%C3\%BCrkiye deki\%20Suriyeli\%20\%C3\%87ocuklarBilgi\%20Notu\%20Subat\%20201 $\underline{63}$ adresinden erişildi. 
Windle, J. ve Miller, J. (2012). Approaches to teaching low literacy refugeebackground students. Australian Journal of Language and Literacy, 35(3), 317-333.

Yavuz, Ö. ve Mızrak, S. (2016). Acil durumlarda okul çağındaki çocukların eğitimi: Türkiye'deki Suriyeli mülteciler örneği. Göç Dergisi, 3(2), 175-199.

Yıldırım, A. ve Şimşek, H. (2013). Sosyal bilimlerde nitel araştırma yöntemleri. Ankara: Seçkin Yayınları.

\section{Kaynakça Bilgisi / Citation Information}

Kazu, H. ve Deniz, E. (2019). Kapsayıc eğitim bağlamında öğretmenlerin mülteci öğrencilere ilişkin tutumlarının çeşitli değişkenler açısından incelenmesi. OPUS-Uluslararası Toplum Araştırmaları Dergisi, 14(20), 1336-1368. DOI: 10.26466/opus.612341 